\title{
ThE VALUE OF INTERPASSIVITY FOR EVALUATING SERMON HANDOUTS IN AMERICAN EVANGELICAL CHURCHES*
}

\section{SPENCER DAVIDSON ${ }^{\dagger}$}

Abstract: Interpassivity theory was proposed by Austrian philosopher Robert Pfaller in the 1990's. During the height of the interactive art craze, Pfaller pondered what the opposite form and experience of this art might be. This art would require neither a participate to interact with it in order to complete its artistic expression nor an observer to passively enjoy it hanging on the wall. Interpassive art enjoys itself, providing for its own reception. Thus, in this paper, I have sought to employ interpassivity theory as a means for evaluating sermon handouts in American evangelical churches. I claim this theory is helpful for identifying ways in which sermon handouts can disrupt worshippers' participation in Trinitarian communication, thus altering the texture of their experience on the whole.

Keywords: interpassivity, sermon handouts, active listening, commodity fetishism, preaching

\section{Introduction}

In Nicolas Poussin's Les bregers d'Arcadie, three Greek shepherds inspect a weathered marble tomb. The boys are shocked at the inscription. They turn to find a fourth figure who knowingly observes them in their discovery of the message inscribed on the tomb, "Et in arcadia ego." Against the backdrop of an idyllic landscape, the boys learn that even in the paradise of Arcadia, death is present. ${ }^{1}$ Likewise, unanticipated revelations about the nature of sacred spaces in the contemporary world invite inspection and corrective action informed by theory. In certain American evangelical churches, preachers use sermon handouts to guide worshippers along as they hear the sermon. ${ }^{2}$

\footnotetext{
* (C)2021 Spencer Davidson

${ }^{\dagger}$ MLitt 2020 University of St Andrews

${ }^{1}$ Nicolas Poussin, Les bregers d'Arcadie, 1638, Oil on canvas, Musée du Louvre. The inscription translates to "Even in Arcadia, I am."

${ }^{2}$ The names of the churches studied for this paper are Walnut Street Church of Christ, Liberty Church, and Central Church of Christ, all in Nashville Tennessee. The handouts were obtained via their websites. For a discussion of various types of sermon handouts, please see page 69 below.
} 
The practice of using sermon handouts in worship is not unique to one faith tradition. The elements of this practice are not fixed, nor are they regulated by scripture. Instead, this practice suits the needs of any particular moment in the life of a congregation. Types of handouts can and do vary greatly. The timing of their deploy can, too. Some worshippers are given their handout on their way into that day's service. Some receive theirs in theirs as emails, days prior to the time of worship. For these reasons and more, these small sheets of paper are perhaps the most malleable aspects of evangelical Christian worship. Ultimately, sermon handouts are tools. When they are used, their use is to advance the meaning, extend the delivery, and preserve the moment the lesson. In this sense, sermon handouts are like other tools. And like other tools, their use should not be accepted uncritically.

Interpassivity theory claims that worshippers are subject to unseen forces that can influence their reception of this practice. This essay will introduce and analyze the theory of interpassivity to consider how interpassivity helps or hinders the evaluation of the sermon handouts' potential value for these churches.

Accordingly, the works of interpassivity's founder, Robert Pfaller will be critically discussed, along with Gijs Van Oenen and Slavoj Žižek who have developed interpassivity in psychoanalysis, political theory, the arts, and popular culture. Interpassivity will be read alongside Trinitarian theology, to outline the impact of its main symptoms: mediation, delegation, and disappearance. This essay will conclude that the theory of interpassivity is helpful to see how, as worshippers complete their worksheets, the worksheets are "doing" work themselves. In turn, these learning tools interact with the texture of the sacramental experience of preaching for worshippers.

Following an appraisal of sermon handouts' value as educational methodology, the weakness and strengths of the practice of distributing these study materials in worship will be analyzed and discussed with particular reference to Pfaller's concept of disappearance within interpassivity theory. This concept, describing detachment from experience for interpassive subjects, will be put forth as a key symptom of interpassivity within the practice of using worksheets. This essay will ultimately claim that interpassivity theory is helpful for developing worksheets that maximize the interior experience of worshippers because it opens worksheets up to broader critique for the impact they have on directing worshippers' enjoyment of the sermon.

Like Poussin's shepherds, whose bucolic Arcadia is presented as a plane upon which heaven and earth meet, Christians can discover a seemingly inapposite figure in a most sacred 
space. The message awakens the boys to the reality of the metaphysical force of death and the impact it has on life in Arcadia. As the somber fourth figure suggests, death's presence must be acknowledged, even within the realm of gleeful shepherds, and not merely acknowledged - death must be lived with.

Interpassivity can provide a similar surprise to Christians who assume there is nothing lurking within their practices in worship that could jeopardize the potency of worship. Yes, singers can be flat and church buildings do flood on occasion. Interpassivity, by contrast, does not uproot the pleasure of experience. Instead, it is the pleasure of experience. Pfaller's work exposes interpassivity as the delegation of enjoyment. ${ }^{3}$ What is crucial for interpassivity is its subliminal role in everyday life. Subjects may enjoy an experience and be unaware that they are enjoying through an object. In interpassivity, the pleasure of delegating passivity, where objects take on a part of experience for interpassive subjects, becomes an additional and prominent pleasure of experience. Accordingly, the helpfulness these handouts, available to the public via the churches' websites, can be more thoroughly evaluated by interpassivity theory.

This essay will advance the view that interpassivity shifts the texture of experience of interpassive subjects. This shift is articulated in the "graying of experience" observed in certain cases when new technology is introduced in the workplace. ${ }^{4}$ The change from provincial work benches to Fordist assembly lines can be read as one in which substance is exchanged for yield. ${ }^{5}$ The modality of worship is subject to causing similar changes. The practice of distributing handouts to congregants to complete as the sermon is being preached will be discussed accordingly.

What is at stake for worshippers is the utility of handouts as learning aids and the enjoyment of the communal nature of preaching. This essay will show how preaching functions as an experience that is beyond rhetoric. Rather, the sermon exposes worshippers to Trinitarian speech that can be received and responded to in reflection, instruction, and anticipation. Interpassivity delegates the labor of this experience to objects, sermon handouts, which present themselves to

${ }^{3}$ Robert Pfaller, Interpassivity: The Aesthetics of Delegated Enjoyment (Edinburgh: Edinburgh University Press, 2017)

${ }^{4}$ Bryan R. Warnick and David Waddington, "The Gathering: An Ethical Criterion for Educational Technology," Educational Technology Volume 44, Number 5 September-October (2002) 25

${ }^{5}$ The Ford Motor Company pioneered this highly mechanical and predictable style of production during the early 1910 's. 
worshippers to have completed or nearly to have completed the engagement. Moreover, Van Oenen claims interpassivity itself commodifies the labor of worship, covertly reshaping the goal of worshippers to the process of worshipping rather than the production of worship itself.

In this way, interpassivity raises questions about the consequences of distributing the labor of experience in worship. However subtle, the symptoms of interpassivity constitute a challenge to the reception of preaching, which is a sacramental act that "makes something happen." 6 This experience of sacramentality, communion with God, this essay argues, is a worthwhile project for conservation. To engage this participation, rather than enjoy its wholesale delegation is to successfully tame the ambivalence of technology. ${ }^{7}$ The alternative spoils the joys of faith and learning, reshaping worship to be more impersonal and process-oriented.

The tension between yield and substance is characteristic of contemporary life. There is an ethical need to "explicate the deep structures of technology" for today. ${ }^{8}$ These deep structures within technology correspond to being and give to shape "life in a commodified world". ${ }^{9}$ The commensuration of yield and substance, as Albert Borgmann claims, can be managed by contexts of engagement. His understanding of this tension is represented in his theory of device paradigm, which seeks to respond to the challenges of technology by seeing, "an ontology that prompts a phenomenology which in turn implies an epistemology and finally an ethics." 10 This essay will seek to supply the rationale for choosing to do so.

Now, worship is intersecting with technology as a matter of necessity as global pandemics force churches to conduct their services online. This move to embrace technology as sophisticated as live streaming and digital platforms for monetary giving makes it tempting to overlook more humble expedients like sermon handouts. Yet, interpassivity, like the Arcadian tomb and the metaphysical realities it represents, is as near as our contemplation permits.

\footnotetext{
${ }^{6}$ Alison Milbank, John Hughes, and Arabella Milbank, Preaching Radical and Orthodox: Sermons for the Christian Year (London: SCM Press, 2017), 3

7 Pfaller, Interpassivity, 34; Albert Borgmann "Reality and Technology," Cambridge Journal of Economics, 34 (January 2010): 28

${ }^{8}$ Borgmann "Reality and Technology," 28

${ }^{9}$ Ibid, 29

${ }^{10}$ Ibid, 33-153
} 


\section{Preaching and Listening in the Trinitarian Economy}

There is language, there is art, because there is 'the other'. We do address ourselves in constant soliloquy. But the medium of that soliloquy is that of public speech foreshortened, perhaps made private and cryptic through covert reference and association, but grounded, nevertheless, and to the uncertain verge of consciousness, an inherited, historically and socially determined vocabulary and grammar. $^{11}$

Preaching is a matter of Christian faith and practice. This section will argue that preaching is indeed beyond rhetoric, that delivering and receiving sermons is a sacred practice. Accordingly, this section is for examining sermons as events within systematic theology that are Trinitarian by nature to show the potency of congregational worship in the extension of the Trinity's presence and conversation to those who receive the words of God. The reception of this sacred aspect of worship through "active listening" facilitated by sermon handouts will be shown to be a crucial task for worshippers that can be further evaluated by interpassivity theory. Here, the communal aspect of preaching is highlighted to show what is at stake for interpassive subjects who delegate their participation in sermons to worksheets. This value, and its potential erosion, is crucial for evaluating sermon handouts' contribution to Christian worship.

Two otherwise very different views of preaching share one thing: both think of preaching as a relic. The first, citing the influence of technology in the postmodern age, sees preaching as an antiquated practice which is hopelessly ineffective. ${ }^{12}$ The second views it as a sort of ancient sacrament. We might call these the "obsolescent" and the "sacramental" views.

\section{$\underline{\text { Homiletic Obsolescence }}$}

Congregants, the argument goes, now receive their information about the world and take their moral cues from mass media that demands less and can be accessed "on demand." This convenience, paired with the secularization of western life, has contributed to the reception of preaching as an obstacle to, rather than a catalyst for, transformative experiences. Consequently, the Church as an institution has been cast as fading within the "fabric of society." 13 The preaching of sermons is a central event within the worship services of the congregations being considered.

\footnotetext{
${ }^{11}$ George Steiner, Real Presences (Chicago: University of Chicago Press, 1991), 137

${ }^{12}$ Klass Runia, "What is Preaching According to The New Testament?" Tyndale Bulletin 29 (1978): 3-48

${ }^{13}$ Ibid, 4
} 
All three churches in this study fund preachers who work full time with the congregation to preach to specific age groups as well as the general assembly. Moreover, these congregations see preaching as an event for proclaiming and offering a salvific message, after which those in the audience are invited to respond by approaching the stage to confess their belief that Jesus is Christ. ${ }^{14}$ On the institutional level, these churches teach and arrange their worship in such a way that affirms preaching's relevance. Yet, as individuals, worshippers may feel that preaching has become a relic of the past.

It has been suggested that this is partially due to preaching's inherent weaknesses as a form of communication. ${ }^{15}$ When compared to more contemporary methods of communication, the preaching of these churches is one-directional and less interactive. ${ }^{16}$ The congregations under consideration do not choose the sermons they will hear or when they hear them. Church leaders and preachers select the topic and times for sermons with the expectation that members will attend. The general practice of preachers in these churches has been to provide sermons that function as a lecture or motivational speech. Accordingly, these sermons' lack of reciprocity sharply contrasts with modern expectations of communication as seen in the technology that provides more choice and bidirectional expression, deepening the sense of displacement which characterizes the institution as described above.

This view was expanded through empirical studies and shaped by literature which questioned the utility of preaching as an effective educational methodology. ${ }^{17}$ In these studies, few attendees were able to recall the topic of the prior Sunday's message or felt that the experience had much impact on their life. The practice of sermon handouts seeks, in part, to prevent this outcome. Rather, worshippers can sustain their engagement with the message and perhaps recall its contents

\footnotetext{
14 The singing of an "invitation song" corresponds with this response. Note the place this song has in each service. The song is scheduled immediately following every sermon with the expectation that preachers will share a message that should solicit such a response. This is regardless of the topic of the sermon. Further, this song's proximity to the sermon is an important facet for understanding how these congregations associate preaching and salvation.

${ }^{15}$ Runia, "What is Preaching," 3

${ }^{16}$ It is my observation that these churches do not utilize preaching moves that might be less one-directional. Paul's practice within synagogues, which Luke describes as dialgomai (Acts 17:2, 17, 18:4, 19), gives precedent for engaging in open debate, dialogue, and bidirectional communication within a religious gathering. These churches, which share an interest in operating within biblical precedent, have were not observed to engage in such practice for the duration of the research prepared for this essay.

${ }^{17}$ Cf. Clyde Reid, The Empty Pulpit (New York Harper \& Row, 1967), 30ff.; Richard Voelz "Reconsidering The Image of Preacher-As-Teacher: Intersections Between Henry Giroux's Critical Pedagogy and Homiletics," Analyzing Matters, (March 2014)
} 
later. Whatever devotional or documentary advantages this practice supports are further helped by handouts' practical advantage of being easy to transport or store by way of physical or digital means.

However, accessibility and storage for recall is not the primary goal for these churches. The types of handouts provided for this study represent an interest in engaging worshippers on an individual level. Rather than providing manuscripts, preachers circulate handouts with blanks, inviting congregants to have an interactive experience with the material being preached. ${ }^{18}$ This practice transfers or infers some responsibility to the individual subject in the chain of communication. Whether this is a consciously a performative act, matter of faith, or explicitly a matter of church doctrine for these churches cannot be established as the worksheets are provided without instruction. However, the context suggests the aim of these worksheets is to promote engagement with the material being preached beyond listening. In the proceeding chapters, this practice will be analyzed further.

\section{$\underline{\text { Something Sacred }}$}

The other view of preaching as a relic, drawing on homiletic theories carried over from the Reformation, emphasizes the sacramental nature of preaching and enshrines the event of preaching and hearing sermons. ${ }^{19}$ In this sense, preaching is thought of as one would a precious or sacred relic and not in the colloquial, derogatory sense by which this view is contrasted. The congregations under review here organize around a theology which generally corresponds to limiting practices and taught beliefs to those found within the recorded history of early Christians as found in the New Testament. Nevertheless, they incorporate tools to engage sermons that give credence to the critical discussions of sermons related to the former view. Thus, prior to examining the practice of sermon handouts, it is helpful to discuss how these congregations think about sermons and what their assumed outcomes are.

\footnotetext{
${ }^{18}$ Whether this should occur inside or outside the worship service is unclear. Some congregants may choose to complete their handouts in the days following the original delivery of the sermon to test their ability to recall the contents of the message or to provoke their own private reflection on the subject matter. However, this essay will limit the discussion of interaction with sermon handouts to engagements during the worship service.

${ }^{19}$ A. Skevington Wood, Captive to the Word: Martin Luther, Doctor of Sacred Scripture (Exeter: Paternoster,1969) $89 f$.
} 
The Reformation revived the priority of preaching as essential Christian practice. ${ }^{20}$ Reformers pressed preaching as a means by which heretics could be refuted, exposed, and warned of eternal torment and the faithful could be comforted and educated about the faith and the world around them. Tensions between Reformers and their opponents fueled interest in preaching as a venue for doctrinal combat. Sermon worksheets suggest this interest carries through to the churches in the present discussion when they engage the purported views of other religious groups. Again, the mobility of these worksheets supports a process in which congregants can obtain a script for addressing divergent views at their weekly service and then take this script with them in anticipation of being required for confronting whatever heterodoxies they might encounter during the week. In this way, sermon handouts reinforce a way of thinking about sermons that claims Sunday's message should not be forgotten. Through this practice, these churches hint that the words of the preacher, in some sense, should be honored by recording. In this way, each worshipper who participates in completing sermon handouts becomes an amanuensis for the preacher, whose words, like the preachers of the New Testament, are written down and distributed among the faithful.

Yet, these churches do not regard the message their preacher is sharing is new or unique. Instead, the words of the sermon merit such reverence because they are old words. This view connects the sanctity of sermons to a message rather than an individual on stage. For these churches, the message of the Scriptures within sermons is a sacrament. And the Scriptures, which these congregations endorsed as a matter of doctrine as being God-breathed, further develop sermons as sacred events:

The Gospel, however, is nothing else than the preaching and proclamation of the grace and mercy of God which Jesus Christ has earned and gained for us through his death. It is properly not something written down with letters in a book but more an oral proclamation and a living word: a voice which sounds forth into the whole world and is proclaimed publicly so that we may hear it everywhere. ${ }^{21}$

Accordingly, the intellectual agenda within these churches promotes a sacramental view and practice of sermons.

Biblical theology can be used to support this view. At times, the text treats God's presence with the same level of mobility as the spoken or written word so that communion with God can

\footnotetext{
${ }^{20}$ R.T. Kendall, "Preaching in Worship," Themelios, (April 1979): 2

${ }^{21}$ Paul Althaus, The Theology of Martin Luther (Philadelphia: Fortress 1966), 73.
} 
take place in a variety of settings. The "nearness" of God, in this sense, is limited only to one's proximity to words that originate from God. ${ }^{22}$ In other words, "God is present where God speaks." ${ }^{23}$ Benjamin Blair Phillips is a systematic theologian whose views of divine presence in preaching will be expounded upon later in this chapter. His work in homiletics claims God's presence in preaching. Phillips sees this expectation in Moses' promise to Israel: "For this commandment which I command you today is not too difficult for you, nor is it out of reach. It is not in the heavens...but the word is very near you, in your mouth and in your heart, that you may observe it." (Deut 30:11-14) Phillips argues that this presence is now mediated through various means, including preaching. ${ }^{24}$

However, this means more than reading the text aloud. ${ }^{25}$ The mediation of the preacher is to facilitate a communion experience. ${ }^{26}$ With this comes didactic responsibilities and vocational authority, shaping the role of preachers within Christian worship settings. ${ }^{27}$ The possibility of this role is suppressed by some homiletics scholars who argue that preachers are theologically bound to sharing only the "bare facts" of the Gospel to persuade unbelievers. ${ }^{28}$ Attempts to sharply divide the acts of preaching and teaching disrupt theories like Phillips' and the logic of congregations whose practice is to enhance their experience of sermons with handouts. Whatever nuances that characterize teaching and preaching as individual actions do not substantiate claims that they are always mutually exclusive.

This argument is made by pressing the vocabulary of the New Testament. ${ }^{29}$ However, the force of these proofs for today is limited. C.H. Dodd's formulaic treatment of biblical vocabulary insists that preaching is always public and teaching is always private. ${ }^{30}$ Audiences in the public should hear preaching because they need to be persuaded to accept Christ, whereas audiences in

${ }^{22}$ John Frame, The Doctrine of the Word of God (Phillipsburg, NJ: P \& R, 2010), 64

${ }^{23}$ Kevin Vanhoozer, Remythologizing Theology: Divine Action, Passion, and Authorship (Cambridge: Cambridge University Press, 2010), 238

${ }^{24}$ Benjamin Blair Phillips, "Fellowship of the Triune God: The Divine Context for A Theology of Preaching," The Journal of the Evangelical Homiletics Society 16, no. 2 (September 2016): 22

${ }^{25}$ Arthur Rowe, "Preaching and Teaching," Evangel 17:2 (Summer 1999) 4

${ }^{26}$ Ibid, 2

${ }^{27}$ Ibid, 4

${ }^{28}$ Robert C. Worley, Preaching and Teaching in the Earliest Church (Philadelphia: Westminster, 1967), 21.

${ }^{29}$ Ibid

${ }^{30}$ This is seen elsewhere, such as in Richard Voelz, "Reconsidering The Image of Preacher-As-Teacher: Intersections Between Henry Giroux's Critical Predagogy and Homiletics," Analyzing Matters March 01, 2014; Michael Quicke Preaching Outcomes Evangel Summer 19912 
worship services of the Church must be taught moral lessons to accompany their faith. This formula has been dismissed by other biblical theologians because it assumes Christianity's message will always be nascent. The practical distinction between kerygma and didache for the contemporary world is quashed in view of the West's general awareness of the Christian narrative. $^{31}$

Yet, even the historical application of this formula cannot sustain its authority as orthodox Christian practice. Jesus clearly taught "disciples" in the public square during the Sermon on the Mount, and Paul preached so long in a private setting that Eutychus fell asleep and tumbled out of a window. Linguistically, this argument is challenged by other biblical theologians who cite the New Testament's use of kreussein alongside didache to show that "proclaiming" coincides with teaching in a variety of settings. ${ }^{32}$ Accordingly, Robert O’Lynn sees preaching as a process of communication. ${ }^{33}$ This allows the role of the preacher as a mediator of a sacramental experience to incorporate educational methodologies into its practice as well as proclaiming "bare facts" about the Gospel.

O’Lynn observes three "structures" for preaching sermons: Law/Gospel, Trouble/Grace, and Orientation, Disorientation/New Orientation. ${ }^{34}$ These structures are designed to shape how preachers facilitate sermons as sacramental events with transformative qualities. Worshippers, through the sermon, engage rhetoric of being - beyond commercial solicitation or cultural commentary. These structures are categories for shaping one's spiritual perception and engaging theology in practice. The first seeks to help worshippers successfully transition their frame of reference from the Old Testament to the New Testament. The second helps them contextualize hardship as an affirming experience of their standing in Christ. O'Lynn's final structure seeks to orient worshippers in such a way that all life can be read through the anticipation of Christ's return.

\footnotetext{
${ }^{31}$ Clark M. Williamson and Ronald J. Allen, The Teaching Minister (Louisville, Ky.: Westminster/John Knox, 1991), 7.

32 Arthur Rowe "Preaching and Teaching," Evangel 17:2 (Summer 1999) 4

33 Robert O’Lynn, “Developing a Transformative Theology for Preaching," International Journal of Homiletics, 3 (2018), 99-111.

34 Ibid, 4
} 
Over time, critical discussion among homiletics scholars has influenced how preachers think about these structures and what their congregations might expect in hearing them. ${ }^{35}$ Nevertheless, O'Lynn believes these structures are theological rather than merely practical. They elevate preaching beyond rhetoric and deploy sermons in a manner that corresponds to theological metanarratives of salvation, love, and advent, demonstrating how preaching can engage practical methods for achieving theological outcomes.

Phillips suggests preaching can be a Trinitarian event. ${ }^{36}$ This outcome, couched in systematic theology, can be achieved for churches through practices which facilitate worshippers' abilities to participate in the "economy of Trinitarian speech." ${ }^{37}$ Phillips sees preaching as a means of mediating access to the "community" of the Trinity. ${ }^{38}$ This community is in conversation. No other action in the Bible is associated with God like speech. ${ }^{39}$ Phillips posits that Trinitarian speech itself distinguishes the character of divine Persons and is the clearest way of understanding how these Persons relate to one another. ${ }^{40}$ Speaking, however analogical, is a part of God's nature. ${ }^{41}$ Between Father, Son, and Holy Spirit, there is continual "mutual glorification" in eternity. ${ }^{42}$ Yet, in creation and incarnation, the Trinity demonstrates a desire to extend fellowship through a pactum salutis (covenant of salvation). ${ }^{43}$

This divine desire, made in eternity, charges the Biblical narrative. Paul could be suggesting this in the Epistles, recognizing the choice of the Trinity to save in Christ "before the foundation of the world" [Ephesians 1:4]. This would be "according to his own purpose and grace, which was given us in Christ Jesus before the world began". [2 Timothy 1:9] Humanity's origins on the earth, whose very formation is a result of Trinitarian speech, is blessed by divine agreement.

${ }^{35}$ Milton J. Crum, Manual on Preaching. A New Process of Sermon Development, (Valley Forge: Church Publishing 1977, 71-86;

Paul Scott Wilson, Preaching and Homiletical Theory, Preaching and Its Partners Series, (St. Louis: Chalice Press 2004), $73 \mathrm{f}$.

${ }^{36}$ Benjamin Blair Phillips, "Fellowship of the Triune God: The Divine Context for A Theology of Preaching," The Journal of the Evangelical Homiletics Society, (September 2016), 16

${ }^{37} \mathrm{Ibid}, 24$

${ }^{38}$ Vern S. Poythress, In the Beginning Was the Word: Language, A God-Centered Approach (Wheaton, Ill.: Crossway, 2009), 18

${ }^{39}$ Kevin Vanhoozer, Remythologizing Theology: Divine Action, Passion, and Authorship (Cambridge: Cambridge University Press, 2010), 212

${ }^{40}$ Phillips, "Fellowship of the Triune God," 18

${ }^{41}$ Ibid, 19

42 Vanhoozer, Remythologizing Theology, 241

${ }^{43}$ Ibid, 77-88 
"Let us make man in our image" [Genesis 1:26] is not simply a sort of "royal "we'," but grammatically and theologically reflects a triadic communication "without which God would not be God." 44 Phillips presses that the sending of the Son is a result of this decision, made in eternity, and in reaction to the "temporal" event of the Fall. ${ }^{45}$ While on Earth, the Father and Son continue to recognize one another by speech. ${ }^{46}$ Thus, "This is my Son with whom I am well pleased" [Matthew 3:17, 17;5, Luke 9:35] and "O Father, glorify Me together with Yourself, with the glory which I had with You before the world was" [John 17:5] are part of a continuing Trinitarian conversation.

The preaching of the Son reaffirms this union which is beyond association; the Father indwells the Son just as the Spirit does "without measure" (John 3:34). ${ }^{47}$ The image of salvation, as expressed by the Son is one of similar union:

I do not ask for these only, but also for those who will believe in me through their word, that they may all be one, just as you, Father, are in me, and I in you, that they also may be in us, so that the world may believe that you have sent me. The glory that you have given me I have given to them, that they may be one even as we are one, I in them and you in me, that they may become perfectly one, so that the world may know that you sent me and loved them even as you loved me. (John 17:20-23).

In this prayer, Jesus, recognizing the joint participation between himself and the Father, expresses his desire to expand this unity to include his disciples. As he prays, Jesus is indwelled with the Holy Spirit. This constitutes a Trinitarian presence and dialogue. Here, readers are only made aware of the words of one Person of the Trinity. However, in his Gospel, John records one instance in which Persons within the Trinity engage in speech directly among themselves. ${ }^{48}$ Human disciples of Jesus, therefore, can anticipate similar engagements as members of the same union. This union is effectuated in baptism, in which subjects are buried and lowered "with" Christ (Col 2:12). Paul says such union is both symbolic and interior. For, God sends, "the Spirit of his Son into our hearts, crying, "Abba! Father!" (Gal 4:6)

\footnotetext{
${ }^{44}$ Frame, The Doctrine of the Word of God, 35

${ }^{45}$ Phillips, "Fellowship of the Triune God," 18

46 Ibid, 17

47 Ibid, 19

${ }^{48}$ See John 12:28, where Jesus speaks out and is responded to by the Father from heaven. This demonstrates a chain of communication among divine Persons that resembles the practice of humans.
} 
Phillips describes this union as one in which the Trinity is experienced rather than expanded. ${ }^{49}$ This experience is sacramental, allowing humans to reflect the sacred economy of communication, unbroken in eternity, as imago Dei. ${ }^{50}$ The union, in the soteriological sense, is fulfilled in receiving Jesus Christ. Yet, as previously mentioned, God's presence and the opportunity for sacramental experiences therein is dynamic. ${ }^{51}$ Events in which the presence of God can be experienced by groups of people are subject to heightened reflections of this economy. For Phillips, preaching is the act of mediation that grants this experience for this setting. ${ }^{52}$

And this is not achieved through the skill of the preacher. Instead, it is exposure to the power of words that have been "communicated in eternity" that charge preaching as a theological event. ${ }^{53}$ These words are used by the preacher whose role is to communicate in such a way that the nature of the Trinity is revealed. ${ }^{54}$ Phillips says these words are recovered by the preacher, who is first an auditor of "intra-Trinitarian" speech. ${ }^{55}$ This, too, reflects the triadic behaviors of God: "Christ spoke only what he had heard the Father say. The Spirit also speaks what he has heard. Just as the Spirit is the eternal auditor of the divine conversation, now he causes people to hear. Just as the Spirit says only what Christ has given, who in turn has spoken only what the Father has said, so also the preacher may only say what God has said through the prophets and apostles." 56

The sacramental quality of sermons appears as the message, heard first from God, is repeated for and heard by a congregation. This extends fellowship by way of "overhearing" a sacred conversation, mediated by the preacher. ${ }^{57}$ Thus, listening becomes a theological event as well. Homiletics scholars suggest that in at least one way, the roles of preacher and congregantauditor unite as that of "active listener." 58 This fellowship reflects communication models for the inter-Trinitarian speech, forming another trinity in which, as we shall see below, congregations, preachers, and the Godhead are listening to divine conversation. In this sense, the pedagogical

\footnotetext{
${ }^{49}$ Phillips, "Fellowship of the Triune God," 17

50 Ibid, 21

51 Ibid, 22

52 Ibid, 23

53 Ibid, 23

54 Ibid, 22

55 Ibid, 23

${ }^{56}$ Ibid, 23-24

57 Ibid, 24

58 Two sources which consider active listening within the congregation are: Fred B. Craddock, As One without Authority, Rev. ed. (St. Louis: Chalice, 2001), 27; Voelz, "Reconsidering The Image,” 80
} 
practice of preachers is a form of ecclesiology, elevating voices within a community for the purpose of influencing transformational changes. ${ }^{59}$

\section{$\underline{\text { Responding to The Sacred }}$}

Critical discussions of preaching as a function of ecclesial practice lead to the examination of outcomes. ${ }^{60}$ Here, progress can be made by asking what audiences should "do" with preaching rather than merely asking "how" they listen to preaching. Ways in which audiences take up active or passive roles will be considered in subsequent sections in anticipation of a review of how sermon handouts might impact the theological and educational outcomes desired for the churches using the handouts. Here, qualitative language can begin to be applied to preaching events, suggesting what "good" preaching may or may not be for particular churches depending on their theological agendas.

Preaching is so central to Christian faith and practice that it has been suggested that the church cannot "be" the church without it. ${ }^{61}$ Accordingly, cultures of affirming the preacher are known in churches of all kinds. ${ }^{62}$ Expressing feelings of a job "well done" to the preacher may differ among tradition and cultural context, but the reality of some desired outcome for preaching is implied in every case. These outcomes can correspond to achieving the secular, social goals of the congregation or support an intellectual agenda as confirmation bias. The criterion among congregations will differ. Some will measure success by the emotional appeal of a sermon, others will gauge the level of intellectual stimulation or some other metric.

Efforts to scientifically measure success have been deemed excessive but helpful for determining what categories of outcomes for preaching might be. ${ }^{63}$ Biblical theologians see outcomes in the text of the New Testament. ${ }^{64}$ The "range of responses" includes astonishment, antagonism, conviction, conversion, strengthening, encouraging, and comforting. These correspond to outcomes proposed by Robert O’Lynn. ${ }^{65}$ Curiously, he posits three general

\footnotetext{
${ }^{59}$ Burton Z. Cooper and John S. McClure, Claiming Theology in the Pulpit, 1st ed. (Louisville: Westminster John Knox, 2003) 137

${ }^{60}$ Linn Sæbø Rystad, "I Wish We Could Fast Forward It: Negotiating the Practice of Preaching," Homiletic 44 (2019): 38

${ }^{61}$ Robert O’Lynn "Developing a Transformative Theology," 99

${ }^{62}$ Michael Quicke "Preaching Outcomes," "Preaching Outcomes" Evangel Summer, Volume 17 (1991): 1

${ }^{63}$ K.I. Pargament and D.V. DeRosa: 'What was that sermon about?" Journal for Scientific Study of Religion 24 (1985) pp. 119-236; Michael Quicke "Preaching Outcomes" Evangel Summer, Volume 17 (1991): 1

${ }^{64}$ Ibid. 3

${ }^{65}$ Robert O'Lynn "Developing a Transformative Theology," 108
} 
categories which work together to facilitate transformation within the audience. These categories complete a trinity of trinities for preaching: the Father, the Son, and the Holy Spirit, the Triune God in dialogue with the preacher and the audience, and categories of outcomes for preaching that are instruction, reflection, and application. Thus, these churches seek to facilitate the reception of sermons. They sense that something beyond rhetoric is taking place. However educational or inspiring, sermons ultimately invite worshippers into sacred space. In the next section, we see that sermon handouts are deployed as "guides" into this space.

\section{Sermon Worksheets and Educational Methodology}

By design, Christianity advances with the sharing of "good news." Among numerous practical gestures, Christ also published his doctrine through preaching. Perhaps a subtle nudge to suggest the primacy of preaching among these is given by Matthew, who describes Jesus' habits in this way: "And he went throughout all Galilee, teaching in their synagogues and proclaiming the gospel of the kingdom and healing every disease and every affliction among the people." (Matt 4:23) The placement of teaching and proclaiming here, coming before even the miraculous, captures the high esteem preaching enjoys within the churches under review in this essay, who continue the tradition of preaching as a primary method of promoting Christianity.

Preachers are expected to deliver sermons that lead congregants into places of deeper understanding, faith and practice. Accordingly, sermons are delivered to educate as well as inspire praise, comfort, and reflection. This section will describe the value four types of sermon handouts have as educational tools. Critical discussion of worksheets within similar fields of education will show the qualities of worksheets and their role in learning environments. This is necessary for theoretical reading of this practice by interpassivity, concluding that worksheets deployed as aids to sermons can and do introduce an additional presence in the assembly. The role and impact of this presence in Christian worship is central to discussing how interpassivity helps evaluate sermon handouts for Christian worship and ultimately establishes guidelines for developing these handouts.

Although preaching has an essential goal of informing worshippers, and even though traditionally most Christians receive their theological education in church, ${ }^{66}$ homiletic literature

${ }^{66}$ J.A. Mercer, "Transformational Adult Learning in Congregations," The Journal of Adult Theological Education 3:2 (2006): 163 
largely ignores educational theory. ${ }^{67}$ Preaching is more commonly associated with communication theory or public speaking. The breadth of homiletic literature surveys sermon composition, how sermons might achieve the theological goals of the preacher, and what the milieu of preachers should aspire to be. John Stott concludes, "To expound scripture is to open up the inspired text with such faithfulness and sensitivity that God's voice is heard and his people obey him." 68 While effective to these ends, homiletics has yet to be synthesized with educational theory to the extent that it is deployed for educational purposes.

In The Practice of Preaching, P.S. Wilson suggests sermons should balance theology and rhetoric. ${ }^{69}$ This revives the historical, Augustinian view that preaching is shaped by theology as well as educational theory. For Christian preaching, Augustine urges Cicero's rhetorical strategy to "teach, to delight, and to persuade." 70 The importance of the persuasive element within preaching is underscored when modern homiletic literature cites change - conversion, repentance, metanoia -- as preaching's ultimate goal. ${ }^{71}$ Like preaching, human learning theory supports growth through change. The space in which theorists claim this change occurs is one of persuasion, education, and discourse between teacher and student. Johnathan Stuart applies this theory of transformative learning to homiletic methodology. ${ }^{72}$ Stuart sees the sermon as "the transcendental site where speaker and hearer meet, where they can reciprocally raise claims... and where they can criticize and confirm those validity claims." 73 This application locates the sermon within the hearer as a primarily internal experience in which the message is critically engaged.

Here, it is important to note the similarities this claim shares with Phillips'. Both Stuart and Phillips see the interior of the worshipper as a venue for metaphysical exchange. The Trinitarian context of this exchange, Phillips proposes, broadens the conversation beyond the

\footnotetext{
${ }^{67}$ Johnathan Stuart, "Applying Adult Education Principles within Church Sermons: Some Theoretical Implications," Journal of Adult Theological Education 8:2 (2011): 115

${ }^{68}$ John Stott, "A Definition of Biblical Preaching," in The Art and Craft of Biblical Preaching: A Comprehensive Resource for Today's Communicators, ed. Haddon Robinson and Craig Brian Larson (Grand Rapids: Zondervan 2005), 14-20.

${ }^{69}$ Paul Scott Wilson, The Practice of Preaching (Nashville, TN: Abingdon 1995), p16-18

${ }^{70}$ Augustine, "On Christian Doctrine, Book IV" 4.12.27. https://www.newadvent.org/fathers/12024.htm

${ }^{71}$ This is widely discussed in: Lori Carroll, "Communication Training for Clergy: Exploring Impact on the Transformative Quality of Sermon Communication," Communication Education 58, no. 1 (2009):15-34; Haddon Robinson, Biblical Preaching (Grand Rapids: Baker 1980); Stott, "A Definition of Biblical Preaching," 14-20

${ }^{72}$ Stuart, "Applying Adult Education Principles," 115.

${ }^{73}$ Stuart is applying Habermas here: Jurgen Habermas, The Theory of Communicative Action, Volume 2. (Boston, MA: Beacon Press 1987) 126
} 
preacher, the worshipper, and the message to include the Father, the Son, and the Holy Spirit. ${ }^{74}$ Together, Stuart and Phillips, reveal the underlying conversation within preaching in which divine Persons, having revealed their interior dialogue through the Scripture, can "speak" to the interior of human persons whose reception of Scripture is being managed by a preacher through a sermon. As Stuart suggests, this conversation is labor-intensive. The work to engage, analyze, and respond to the message is demanding. Rather than empty consumption, the worshipper is engaging in metaphysical labor. The labor of conversation is then redistributed to the other members within the economy of the conversation. And it is helpful to reinforce the idea of economy for thinking about this relationship. In the proceeding sections, the theological and educational ideas stated here will be brought into relationship with Marxist theory to show how this conversation can be helped and hindered by the practice of sermon handouts. While it would be possible to study closely how the labor of conversation is experienced by the preacher receiving a message from the worshippers or God receiving a message from the preacher and how certain practices influence this economy, the scope of this essay is limited to how the theory of interpassivity helps to evaluate sermon handouts' potential value for these congregations.

Sermons, like other educational enterprises, are concerned with factors that impact the prosecution of their subject matter. For these congregations, the reception of sermons is so important that their buildings are laid out in a way that centralizes the preacher and the message. ${ }^{75}$ The seating in these worship spaces is arranged to face a stage with large projection screens on either side, where the message and contributing visual cues are displayed via PowerPoint. Each of the congregations represented here worship in modern buildings with minimal adornments and simple architecture. The worship space is the largest and most accessible space in the building, featuring plain walls and little (if any) decoration. Such design focuses worshippers on engagement with sermons. Accordingly, sermons enjoy the benefit of being deployed within a space that is dedicated to their reception. ${ }^{76}$

\footnotetext{
${ }^{74}$ Later, it will be more clearly stated that the delegation of participation in this interior life by worshippers is at the heart of this essay. For now, it is crucial to lay the groundwork for understanding the systems by which this interior life consists of.

${ }^{75}$ These details can be discovered via content produced by these churches and uploaded to their websites.

76 This is to draw contrast between the worship spaces these churches maintain and other places sermon might be heard such as busy markets, loud city streets, or outside in the harsh elements.
} 
This design also accommodates the preacher's goal of effecting change within congregations. Stuart says the pastoral relationship and spiritual environment that accompany sermons obviates the "disorienting dilemma" associated with forms of education that destabilize or challenge audience's overall mental framework or views of a specific issue. ${ }^{77}$ Thus, efforts to make these spaces as plain and unthreatening as possible counterbalance messages that challenge and reform. Being spaces formatted for introspection, worship services are equipped to facilitate the andragogical exercise of "critical reflectivity."78 This method of education encourages learners to examine their assumptions apart from their cultural or historical prejudices and, in concert with the educator, move to resolve or unpack these assumptions. Stuart believes that sermons can be as successful in worship services as lectures are in classrooms, if not more so.

Others are doubtful. Peter Jarvis researches religious experiences and their impact on personal hermeneutics. ${ }^{79} \mathrm{He}$ argues that the emotional experience one might have during a destabilizing sermon results in "disjuncture" as a result of a lack of interpretation skills. Such "creature-consciousness." which Rudolf Otto describes as "the emotion of a creature, submerged, and overwhelmed by its own nothingness in contrast to that which is supreme above all creatures," ${ }^{80}$ serves as the backdrop of Jarvis' depiction of religious experience. The greater the experience, or in this case, sermon, the more pronounced response from the subject will be. In his model of disjunction, subjects have a sharp, transformative response and, for lack of descriptive or interpretative ability, eventually return to their original point of understanding. Accordingly, he doubts the traditional methods and venue of sermon delivery can adequately shelter the "dissonant spark to create a learning experience." 81

Homiletic literature, synthesized with broader educational methodology, presents alternative views of what sermons can or even should accomplish. Beyond this synthesis are the practical methodologies of education which interact with philosophical theories like interpassivity. One such practice is the distribution of worksheets that correspond to the sermon being presented.

\footnotetext{
${ }^{77}$ Stuart, “Applying Adult Education Principles,” 115

78 Jack Mezirow "A Critical Theory of Adult Learning and Education," Adult Education 32, no. 1 (1981): 3-24. doi: $10.1177 / 074171368103200101$.

79 Peter Jarvis "Religious Experience: Learning and Meaning," Transformation 25 (April 2008): 65-72. doi: $10.1177 / 026537880802500301$.

${ }^{80}$ Rudolf Otto, The Idea of the Holy: An Inquiry Into the Non-rational Factor in the Idea of the Divine and Its Relation to the Rational. (Harmondsworth, Penguin) 9

${ }^{81}$ Stuart, "Applying Adult Education Principles," 122
} 
The question of interpassivity within this practice will be weighed against studies of similar practices in other educational settings. This review will reflect how sermon worksheets might support the mission of the preacher as helpful aids or take on entirely new roles as interpassive subjects themselves.

Research touching the use of worksheets in educational settings is limited. ${ }^{82}$ However, the use of teaching aids such as PowerPoint for churches is widespread. To begin the discussion of worksheets and frame the experience of sermon aids in general, Ian Kinchin's review of the conflation of these is a natural starting point. He begins by introducing PowerPoint as experienced in the classroom by a former university lecturer returning to class as a student, who writes under the assumed name Tom Ward. ${ }^{83}$ Ward describes a lecture that has been taken over by a tool. The effort made to improve upon a traditional lecture format is turned on its head and instead presents as a barrier to engagement. "PowerPointlessness," the minutia of attending to the tool and the corresponding lack of real interaction between student and instructor, characterizes his view of the aid. Kinchin suspects the ubiquity of PowerPoint is unintentional as the technology was initially incorporated into educational settings as a novel alternative to other aids. ${ }^{84}$ And it is from this mundanity he posits the next "lazy and ridiculous" generation of classroom aids will come. ${ }^{85}$

The sample churches in this section receive worksheets to complete during the sermon. These worksheets correspond to both the sermon they are hearing and the PowerPoint presentation that is projected on overhead screens. Some worksheets vary only slightly to what is being displayed overhead and simply provide blanks for congregants to fill in as the corresponding line is read or spoken by the preacher and displayed on the PowerPoint presentation. Here, the churches fully integrate the practice Kinchin critiques for classrooms. To the contrary, this practice has been viewed favorably by some educators. Worksheets can be rolled into other educational methodologies and successfully added to curriculums in classrooms or church assemblies. These reviews will be brought into relationship with the theoretical concerns of Pfaller in a forthcoming section.

\footnotetext{
${ }^{82}$ Ian Kinchin, "Developing PowerPoint handouts to support meaningful learning," British Journal of Educational Technology 37 (2006): 647-650

${ }^{83}$ Tom Ward, "I Watched in Dumb horror," The Guardian, 20 May 2003

${ }^{84}$ Ian Kinchin, "Developing PowerPoint handouts," 647-650

${ }^{85}$ Edward R. Tufte, "The cognitive style of PowerPoint" Graphics Press (2003): 22
} 


\section{Types of Sermon Handouts}

Worksheets tend to fall into four general categories. These categories are "blank", "fill in the blank", "oversaturated", and "mixed" and relate to an unscientific description of the types of questions featured on the worksheets. Blank work sheets present the themes or statements from a sermon and provide lines for congregants to add their own thoughts or information from the sermon or PowerPoint. ${ }^{86}$ For medical education, this form of supplemental worksheet is thought to encourage independent learning among pre-clinical students. ${ }^{87}$ Worksheets with spaces to write, doodle, and record connecting ideas are considered active learning tools, and offer an alternative for those whose preference is not to "passively" listen to lectures. ${ }^{88}$ Also, personal annotations increase the student's ability to recall otherwise ambiguous concepts. ${ }^{89}$ These worksheets can reveal potential diversities within study groups. This diversity can enhance relationships among students as they compare their respective worksheet notes. Such encounters have been observed in pre-clinical students who are interested to learn how their peers were thinking about the material, even preferring student notes over supplemental material from textbooks. ${ }^{90}$ For churches, Stuart sees diversity as essential for proper functionality, and the popularity of journaling Bibles suggests open-ended, blank worksheets can be an effective educational methodology for preachers to employ. ${ }^{91}$

On the opposite end of the spectrum, worksheets that are simply oversaturated with information complicate congregants' experience. Note-taking is already cognitively demanding, 92 oversaturating an already rich experience with overwhelming fonts, facts, and fronts of

${ }^{86}$ It is important to note that worksheets are rarely totally blank. Instead, they feature the church's branding and some peripheral information to orient visitors. Acknowledging this is crucial for future discussions about interpassivity, in which these worksheets perform the labor of engaging the message in place of the worshipper by delegation. My claim is that worksheets in this category, blank worksheets (rather than totally blank pieces of paper) present themselves in such a way that reinforces an experience of "disidentification" in which observers experience messages, overly mindful of how the message will be received by a third party. In this case, the third party is called to mind by seeing the branding and logo of the church, making these worksheets subject to being interpassive objects.

${ }^{87}$ Permphan Dharmasaroja "Do Medical Students Really Need Lecture Handouts?" Medical Teacher, 36, No. 10, (2014): 914-915.

${ }^{88}$ Dharmasaroja “Do Medical Students Really Need Lecture Handouts?” 914-915

${ }^{89}$ Farnaz Avval, Lida Jarahi, Kiarash Ghazvini, and Masoud Youssefi, "Distribution of Handouts in an Undergraduate Class to Create More Effective Educational Environment." International Journal of Educational Research. Volume 12:1 (2013):1-6.

${ }^{90}$ Dharmasaroja, "Do Medical Students Really Need Lecture Handouts?" 915.

${ }^{91}$ Stuart, "Applying Adult Education Principles," 117

92 James Hartlely and Allen Cameron, "Some Observations on the Efficiency of Lecturing," Educational Review 20 (1967): 30-37. 
engagement. In other words, they expend excessive "working memory." 93 This concept is used by cognitive psychologists to determine the resources that are drawn to complete tasks such as note-taking. ${ }^{94}$ Worksheets like these demand a high level of cognitive bandwidth to process in real time. Beyond what's on the worksheet, worshippers are decoding messages sent from the PowerPoint presentation, the preacher, and the environment around them. Ronald Larson argues that handouts, however complicated, do not reveal their true benefit to students until the lecture has ended. ${ }^{95}$ The value in graphic-heavy worksheets is in their impact on recall, meaning their potential as interpassive tools is limited.

Japanese researchers in educational theory present the concept of "active learning" as a desirable and contemporary response to the needs of students. ${ }^{96}$ Active learning has become a popular subject; a recent conference paper focuses on ways in which it can be implemented in large university classrooms. ${ }^{97}$ Excellent worksheets are suggested as an example of an active learning tool. The study's ideal worksheet features a blend of reflective questions, space to record individual thoughts, and simple, fill in the blank responses. ${ }^{98}$ Accordingly, their potential as interpassive subjects in Christian worship practices is limited as they encourage students to take a more active role within the learning process.

And roles within worship are critical for discussing interpassivity, theology, and education. Again, Stuart presses that this type of presence is not strictly as evident as the role worshippers play in the African American call and response tradition. "Preaching is a congregational activity" because all have access to (or communion with) God. ${ }^{100}$ Therefore, in some sense, the manner in

\footnotetext{
${ }^{93}$ Worksheets contain elements which correspond to the subject of working memory considered by Alan Baddeley Alan Baddeley, "The Episodic Buffer: a New Component of Working Memory? Trends in Cognitive Sciences." Psychology of Learning and Motivation 4, no. 11 (2000): 417-423

${ }^{94}$ Annie Piolat, Thierry Olive, and Roland T Kellogg, "Cognitive Effort During Note Taking," Applied Cognitive Psychology 19: (2005): 291-312. doi:10.1002/acp.1086

${ }^{95}$ Richard B. Larson, "Enhancing The Recall of Presented Material," Computers \& Education, 53, no. 4 (2009): 1278 1284

${ }^{96}$ Ito Hiroshi "Rethinking Active Learning in the Context of Japanese Higher Education," Cogent Education, 4, no. 1 (2017)

97 Tomohiko Sato, Mami Mitachi, \& Tetsutaro Okada, "Implementation of Active Learning Strategies in a LargeEnrollment Economics Class at a University." Conference: 2018 7th International Congress on Advanced Applied Informatics (IIAI-AAI)(2018): 438-441.

${ }^{98}$ Ibid

${ }^{99}$ Stuart, "Applying Adult Education Principles" 122

${ }^{100}$ Geoffrey Stevenson Preaching with Humanity: A Practical Guide for Today's Church. (London: Church House Publishing 2008) 108; Jeremy Thomson Preaching as Dialogue: Is the Sermon a Sacred Cow? (Cambridge, MA: Grove Book 1996), 7-8
} 
which each worshipper engages in the sermon matters just as much as the manner in which the preacher does. "Conscientization" presses this thought ever further. ${ }^{101}$ This reimagines the traditional hierarchy of sermons being preached down to worshipers with a model of mutual edification, as fellow Christians hear the message together as one unit. ${ }^{102}$

Fill-in-the-blank worksheets draw worshippers and their preachers together by the low possibility of deviation. Methodologies that explicitly reference the worshippers' progress in completing the worksheet only deepen this effect. But, this uniformity among the activity in the pews, in the pulpit, and on the worksheets creates the potential for interpassive practices. Technology that makes a subject or their actions "redundant" and the preacher "superfluous" meets Pfaller's criterion for an interpassive object. ${ }^{103}$ In the forthcoming section, this educational methodology will be brought into relationship with Pfaller's theoretical theory of interpassivity and examined in practice.

\section{Interpassivity and The Labor of Worksheets}

Sermon handouts can also be analyzed and critically discussed for interpassivity. This theoretical development of Jacques Lacan's work has been observed in practices within art, media, political theory, and psychoanalysis. ${ }^{104}$ The utility of this theory for a variety of disciplines extends from its roots in the Marxist concept of "commodity fetishism," which holds that consumers relate to producers through the products they consume. ${ }^{105}$ Interpassivity theory imagines what "theological niceties" may be created or negated when subjects experience mediated engagements with the products they consume. ${ }^{106}$ Robert Pfaller and Gijs van Oenen claim these mediated experiences can result in a liberation that influences the aesthetic and functional qualities of sporting events, political systems, religious ceremonies, and the workplace. ${ }^{107}$ If worksheets are for facilitating the consumption of sermons, interpassivity suggests worshippers may approach the sermons as if they have already engaged them, freeing them to really do whatever they choose.

\footnotetext{
101 Paulo Freiré, Pedagogy of the Oppressed, (Harmondsworth: Penguin 1972) 16-22

102 Stuart, "Applying Adult Education Principles," 122

${ }^{103}$ Gijs Van Oenen, “A Machine That Would Go of Itself: Interpassivity and Its Impact on Political Life," Theory and Event, 9:2 (2006), pp.1

${ }^{104}$ Pfaller, Interpassivity, 26.; Jan Jagodzinski “Interpassivity,” Continental Thought and Theory, 2:1, 270

105 Slavoj Žižek, "The Interpassive Subject,” Lacan.com, accessed August 1, 2020

106 Karl Marx and Friedrich Engels, Capital: A Critique of Political Economy (London: Electric Book Company, 2001), 47

107 Pfaller, Interpassivity, 19-46.
} 
This section will advance the argument that interpassivity identifies how sermon handouts contribute and detract from the experience of sermons.

For the churches under consideration here, sermon handouts are expected to do more than a blank piece of paper might do for congregants. The freedom suggested by a blank piece of paper (even more so if the paper doesn't feature the Church's logo or branding) is exchanged for a prescribed study guide. These handouts alternatively provide a sense of structure to the material being delivered, guiding congregants through the message by giving up only portions of thoughts, verses, or points to be read or presented during the sermon itself. Yet, unlike a blank piece of paper (which one might use for taking notes or making a shopping list or even doodling), these handouts come with calls to action. Whether by overt invitation to fill in the blank when the answer is given by the preacher or by simply being distributed as incomplete, handouts manage engagement with the content of the message.

This allows handouts to "do" more for congregants. Congregants are called to listen and reflect. The handout, an aide to listening and reflecting, yield closer readings of the sermon. Congregants needn't approach the sermon alone; the message can be managed and mediated for them by handouts. As an educational methodology, this practice facilitates active learning and organizes the reception of the sermon on the whole. Congregants, expected to complete the handouts, have less time to engage in lifting their hands, move about in praise, or participate in call and response patterns as seen in other traditions. Thus, handouts shape the worship experience. Enhanced reception of the message diminishes physical freedom and mobility within the assembly. This comes at a cost, however; handouts contribute to an experience of worship overlaid with work-themes as congregants complete assignments that are tools for educating them: worksheets.

Gijs Van Oenen's reading of interpassivity in the workplace is relevant. Interpassivity, he claims, influences the engagement or perception of experiences, their stimuli, or objects under observation. Thus, the experience of production is subject to fetishism as the products in their consumption. Interpassivity is introduced through practices, conditions, and as Pfaller and Žižek theorize, psychological dispositions and ideology within the workplace. ${ }^{108}$ Symptoms of interpassivity can impact the aesthetic and, in this case theological, qualities of labor. Much of this

${ }^{108}$ While Žižek's work in interpassivity theory is prolific, it is beyond the scope of this essay to discuss how interpassivity interacts with ideology. Rather, my aim is to draw from the vocabulary developed by Žižek to discuss how interpassivity is experienced. 
section will outline Van Oenen's symptoms of interpassivity in preparation for a critical discussion of the practice of sermon handouts in the final chapter.

Like the traditional workplace, these congregations worship within a "sphere of labor," Van Oenen's term describing the network of subjects, objects, and the mechanisms they call upon to produce goods. ${ }^{109}$ Production, being central to this network, drives developments of ordering tasks. These tasks invite interpassivity. Thus, parallels can be drawn between traditional "Fordist" workplaces and worship services that assign congregants the task of engaging worksheets. ${ }^{110}$ Yet, this task is not the only work-theme within worship services. The structure of these gatherings suggests a similar, Fordist structure on the whole. The worksheets themselves indicate the hyperorganization of the services. All active participants within the service are listed, along with their assigned tasks. Additionally, the precise order and duration of the service are predetermined. These divisions of labor foil any potential for spontaneity within worship, unlike the practice of early Christians and other contemporary worshippers who do not use worksheets. ${ }^{111}$

More subtly, the practice of dressing up for worship reinforces the work-theme. Because these congregations generally embrace a more formal dress code for Sunday gatherings, preparation for worship might feel like preparing to return to work, where standards of dress are closely monitored as well. And the ones monitoring congregants' dress are not hiding. Rather, they stand at the top of what Van Oenen calls a "fixed, pyramidal" leadership structure for corporations. It is no wonder, then, that the authority figures within these congregations are the sole custodians and wielders of the PowerPoint presentations.

All these individual details come together to support a structure resembling what these congregants may see outside of church meetings at their jobs. The parallels to secular work, the labor of worksheets, the organized response to tasks, limits on time and formality in the ceremony contribute to an atmosphere that commodifies worship. ${ }^{112}$ Accordingly, these practices can be read as supporting a production ethos of worship. This commodification of worship reinterprets the

${ }^{109}$ Gijs Van Oenen, “A Machine That Would Go of Itself,” 1

${ }^{110}$ Van Oenen uses this term to describe industrial labor that has yet to embrace "loose, open network" management styles pioneered by Silicon Valley companies. The Ford Motor Company pioneered this highly mechanical and predictable style of production during the early 1910's.

111 In his first Corinthian epistle, Paul advises the church there to maintain a level of orderliness within worship so that all could "learn". The response of groups like the Quakers, whose worship services include silent and unorganized periods to allow for spontaneous speech by congregants suggest that Paul's doctrine can be observed by methods other than explicit divisions of labor.

112 Borgmann "Reality and Technology," 29 
Psalmist's desire to "make" a joyful noise unto the Lord and invites inspection for latent fetishism within its attendant practices. Otherwise, these practices could simply be thought of as individual parts of the service: singing, communion, giving, etc. This reading sees these as tasks and labor which render worship. Exactly how the "work" of worship intersects with interpassivity will be analyzed in the final section.

If we regard worship as a production, sermon handouts fit right in as part of this labor. But, interpassivity theory suggests these worksheets function beyond simple tools for doing work. Rather, these handouts do work themselves. The interpassivity of sermon worksheets can be seen through Slavoj Žižek's reading of interpassivity within Marxist commodity fetishism. Here, Žižek sees the relationship generated through consumption as interpassive. " $(\mathrm{H})$ ow is it ontologically possible that the innermost 'relations between people' can be displaced onto (or replaced by) 'relations between things'?"113 His point is that interpassivity is one of commodity fetishism's implicit "metaphysical subtleties," which, in order for Marx's theory to operate, must be accepted at some level. ${ }^{114}$ The interpassivity of the labor performed by sermon handouts expands as it is delegated to them by congregants, transforming handouts from active learning tool to interpassive object. Practically, it suggests that products function interpassively without detection despite being engaged in plain sight. As in commodity fetishism, interpassivity functions here as a "metaphysical subtlety" that, regardless of the subjects' awareness, influences the texture of experience.

For theological discussions, interpassivity theory can be used to analyze the nature of sacraments in practice and how sacramentality (communion with God) can be helped or hindered by such practices. Phillips' Trinitarian model of preaching is helpful for beginning such analysis for the practice of sermon handouts. ${ }^{115}$ Here, revelation, produced from the mouth of God, enters a Trinitarian marketplace that, through Scripture, is made available to humanity. Worship settings place the preacher as the mediator of the divine conversation within Scripture for the worshippers. Yet, should the preacher deploy a tool to aid the congregation's participation in the form of a handout, the result is what Žižek describes as "external materiality." 116 The labor of engaging the communication is managed by and perhaps even totally performed externally by the handouts. The

113 Žižek, "The Interpassive Subject"

${ }^{114}$ Marx and Engels, Capital, 47

${ }^{115}$ Benjamin Blair Phillips, "Fellowship of the Triune God: The Divine Context for A Theology of Preaching," The Journal of the Evangelical Homiletics Society, 16:2 (2016) 16-28

116 Žižek, "The Interpassive Subject" 
external material now becomes active within the marketplace as the delegator, consciously or unconsciously, is relieved of the task to consume. Commodity fetishism reveals how handouts are not merely interactive; they are metaphysically in relationship with God through Trinitarian speech. ${ }^{117}$

\section{How Interpassivity "Works"}

At this basic level, interpassivity suggests handouts "do" for the worshipper by relating to the sermon, and by extension, Phillips' Trinitarian conversation. This is perhaps the first step of what may be a total decentering of the worshipper through interpassivity. ${ }^{118}$ A primary function of worksheets for these congregations is to foster belief, yet, through worksheets, worshippers may approach the sermons as if they have already engaged with the material that appears on the page, leaving them free to really do whatever they choose.

First, this may take place through what Žižek describes as "belief at a distance."119 Worksheets externalize belief for worshippers by asserting the belief of others (the preacher, the congregation, deceased members of the congregation, the person who typed and printed the worksheet, the person that distributed it, etc.), thereby serving as sponsors if not guarantors of ideology. Large parking lots and spacious seating in the church building contribute to this sense as well. These signifiers anticipate the advent of believing masses. Videotaping and livestreaming of worship services accelerate the externalization of belief, suggesting an entire internet of believers could be watching. This presents worshippers with the option to believe that others believe (instead of believing that they themselves believe) and thereby believe through others. ${ }^{120}$ Motivations for behaviors shift accordingly, Žižek claims. Now that belief has been decentered, worshippers may very well perform acts of worship, but these are done not for their own belief. Rather, worship is performed for the sake of the belief of what Žižek calls the "big Other." 121 Here, the motivation is to worship as "symbolic efficiency". This term is used by interpassivity to describe the reasons for acting. Rather than acting to prove it to myself, I must act in such a way that the big Other knows it is true as well. Žižek sees symbolic efficiency in parents who celebrate

${ }^{117}$ Pfaller, Interpassivity, 54.

118 Ibid

119 Slavoj Žižek, “Will You Laugh for Me Please?” Lacan.com, accessed August 1, 2020

120 Žižek, "The Interpassive Subject"

${ }^{121}$ Ibid. This term is used by Žižek to describe an imagined, exterior agency for whom we perform but never meet. This is for whom we keep up appearances and trust to guarantee the meaningfulness of our actions. 
(and believe in characters associated with) holidays for the sake of their children's belief rather than their own. ${ }^{122}$ What Pfaller calls ritual and magic, Žižek calls superstitious belief, citing the anthropological anecdote of "primitives" who admit they don't believe that, for instance, their culture originated from a fish, but carry out gestures of belief (rituals, ceremonies, etc.) because their ancestors believed it. ${ }^{123}$ By doing so, they delegate the labor of others. We'll consider where and how this practice fails to be helpful in the final section, in a discussion of disappearance.

Thus, subjects can interpassively perform the labor of belief by consuming worksheets that "do" worship for them. Žižek admits the degree to which this is true can change. The lines are blurred for how, when, and for whom these practices are interpassive. ${ }^{124}$ Yet, the worshippers' awareness of their own decentering is not important. The theory of interpassivity assigns "false activity" to subjects who believe their actions are autonomous but are really being performed for them through objects. Interpassivity at work turns the strategy of handouts on its head, subverting the practice altogether. Žižek sees this paradox in obsessive neurotics whose living practice is to obviate all social tension, but in their frantic attempts to do so (nervous talking, oversharing, etc.) end up creating social tension. ${ }^{125}$ Worshippers may engage sermon handouts with every intention to escape distraction or gain insight into the message. However, interpassivity theory says their actions may result in the very opposite. Here, Pfaller sees the Freudian "leap of reform" in which reformations of practice intended to heighten the experience actually obstruct the exposure of this meaning as the attention shifts to administrating the reform rather than the meaning the reform is meant to expose. ${ }^{126}$

Symptoms of Interpassivity

These critical discussions suggest sermon handouts can be further analyzed by interpassivity theory for unintended ways their inclusion in worship services may influence how these services are experienced. Symptoms of interpassivity reshape how we might think about practices within worship. And these symptoms are not always negative. Pfaller believes

122 Žižek, "Will You Laugh for Me Please?" Even better, when the children admit they only believe because their parents believe that they believe. The children would not get treats and candy from these characters otherwise.

${ }^{123}$ Pfaller, Interpassivity, 54-64.; Žižek, "Will You Laugh for Me Please?"

124 Žižek, "The Interpassive Subject"

${ }^{125} \mathrm{Ibid}$

${ }^{126}$ Sigmund Freud "Obsessive Actions and Religious Practices" in Freud (1953-1974) vol. 7 115-127; Pfaller, Interpassivity, 63. 
interpassivity can strengthen social groups. ${ }^{127}$ Members of these groups enjoy for the sake of the enjoyment of other members. Through "disidentification," the assumed response of other spectators, real or imagined, subjects are decentralized as their enjoyment is delegated to observers. ${ }^{128}$ For example, the collective game played in the stands at large sporting events, "the wave" is fun because we can imagine how our actions appear to onlookers. The enjoyment is not from our own actions, but in the knowledge of how others experience our actions. Thus, we interpassively enjoy the game through the imagined enjoyment of others. ${ }^{129}$ Or consider a performer who, during a benign portion of her act, cautions her audience not to "try this at home". We laugh, because the actor, freeing us from reality, allows us to imagine someone foolish enough to need the warning. Pfaller claims the performer can engage in such uncanny humor only because the is audience willing to act as her accomplice, suspending their doubts and enjoying through an imagined, naïve third party. ${ }^{130}$ Pfaller argues groups can be held together by these pleasures, enjoying the reception of content through "invisible observers" rather than on their own. ${ }^{131}$

Another positive symptom of interpassivity is the pleasure of liberation from autonomous activity through decentralization of the subject. ${ }^{132}$ This is seen in part in the earlier example of the audience members who are freed from engaging with a joke as individual subjects through an interpassive function of disidentification. This symptom expands the freedom of the subject by decentralization functions as a liberating agent, freeing them to pursue and enjoy other thoughts, feelings, and tasks since the task at hand (in this case, the work of reflecting on and learning from sermons) since the work is being carried out by interpassive objects, sermon worksheets. Žižek sees this liberty as a "primordial version of substitution." "133 It is important to acknowledge that he does not immediately condemn this as a distraction. Instead, Žižek sees the pleasure within engagements with "regulated processes" such as performing physical tasks, drill, or completing worksheets. These are opportunities for the mind to be free to consider other matters as the body

\footnotetext{
127 Ibid, 45

128 Octave Mannoni, “Clefs pour I'maginarire ou l'autre scéne” (Paris: Seuil 1985)

${ }^{129}$ Pfaller, Interpassivity, 45.

130 Robert Pfaller "The familiar unknown, the uncanny, the comic, the aesthetic effect of thought experiments" in Lacan: The Silent Partners, ed. Slavoj Žižek (London: Verso) 2005: 211

131 Pfaller Interpassivity, 46.

132 Žižek "The Interpassive Subject." For commodity fetishism, the object is the product through which consumers relate, unknowingly, to producers.
} 
performs work that may be totally unrelated. Discipline of the body, he says, can be liberating for the mind. This is suggested by worshippers who use their sermon worksheets to write down spiritual thoughts of their own, that may or may not even correspond to the sermon at hand. Some churches, perhaps sensing this reality, include some "sanctioned" blank space on their worksheets. In this way, Žižek agrees with active learning theorists who encourage such practices. So, for congregations, interpassivity can be helpful for recognizing the utility of ritual for encouraging thought as well.

Yet, interpassivity can run countercurrent to the theological, educational or ecclesial goals within worship services. As Žižek observes, the pleasure of absence might effectuate the absence of pleasure. ${ }^{134}$ Tools that "do worship" for worshippers may grant the minds of worshippers the pleasure to go elsewhere, but this does not assume the benefits of the work performed by the tool (worksheet) is enjoyed by the interpassive subject (worshipper). This is, for Žižek, capitalism's effect on products, shaped by the market's interpassive delegation of labor (responsibility) of consumption. ${ }^{135}$ The result is coffee without caffeine, beer without alcohol, sugar-free ice cream, and electronic cigarettes. ${ }^{136}$ Accordingly, church leaders may be concerned with worshippers losing "theological niceties" of the message as it is mediated through handouts. The concern for interpassivity's impact on the substance of experience is restated by Gijs Van Oenen. He names symptoms of interpassivity for the capitalist workplace that relate to the question of what might be lost for churches by engaging in practices that support interpassivity in worship. ${ }^{137}$ It is important to see how these symptoms might influence the experiences and practices in a similar context.

Unlike other interlocutors, Van Oenen sees interpassivity as a phenomenon that developed out of capitalist commodity fetishism rather than as an essential part of capitalism itself. ${ }^{138}$ This less radical approach does not insist that interpassive subjects "enjoy their own unhappiness." 139 Nor does he suggest that capitalist societies are held together by mediators that obliterate the 
possibility of directly enjoying anything. ${ }^{140}$ Instead, Van Oenen encourages critical discussion of how the impact of interpassivity within capitalist structures can be managed, despite the changes it has on experience in capitalist societies.

Generally, he says interpassive practices in this context foster experiences of alienation and abstraction for subjects. This detachment is enjoyed as a retreat into a state of pure "selfforgetfulness" (Selbstvergesenheit) rather than Žižek's theory in which subjects always find a more pleasurable activity upon which to ruminate. ${ }^{141}$ And, like other theorists, Van Oenen attributes interpassivity to an increase of activity as the delegation of work decentralizes subjects, liberating them to seek other pleasures. However, Van Oenen believes that, for capitalist production, these other pleasures center around efficiency rather than "hands on" labor. This shift is reflected in the ubiquity of monitoring, adjusting, and supervising tools that have been delegated to perform the work once done manually. Accordingly, interpassivity in capitalist production methods shifts the focus from the final product to the production process subjects are actively engaged in. This theory suggests interpassivity can influence the values of groups as well as their practice.

These theories offer a space in which sermon handouts can be evaluated for their impact on the sacramentality of the worship experience. The final section will contrast Zizekian with readings of interpassivity with those of Gijs Van Oenen, showing how the interpassivity of sermon handouts helps and hinders these congregations' engagement with the preacher's message.

\section{Analyzing the Interpassivity of Sermon Handouts}

"For they know not what they believe" - this would be, in biblical terms, the formula for the civilized position towards the illusion at work in interpassivity. ${ }^{142}$

Pfaller first developed his theory of interpassivity to criticize the trend of interactivity in art installations. ${ }^{143}$ By showing us a new shape of engagement, interpassivity (the inversion of interactivity), he brought forward another way the texture of experience can shift through practice.

\footnotetext{
140 Slavoj Žižek, The Plague of Fantasies (London: Verso, 1997), 111

${ }^{141}$ Pfaller, Die Illusionen der anderen, 203-210. This is not to say that van Onenen trusts interpassive subjects will simply choose not to enjoy profane thought. Instead, he is arguing that interpassivity ultimately negates substance for subjects. So, for Van Oenen, even when Žižek calls our attention to the negation of substance in capitalist phenomenon, he misses a crucial shift in interpassivity's effect. Rather than facilitating ecstasy, Van Oenen posits interpassivity yields efficiency.

142 Pfaller, Interpassivity 58.

${ }^{143}$ Robert Pfaller, Althusser. Das Schweigen im Text, (Munich: Fink 1997)
} 
This discussion of interpassivity in the practice of sermon handouts again unites the themes of practice and experience. Only here, the elements of correspondence and communion remain. The venue of preaching and the worship service can be understood by systematic theology to be space in which Trinitarian conversation is publicly expanded to include the assembly. ${ }^{144}$ Marxist commodity fetishism invites questions about how the introduction of technology -- sermon worksheets -- affects this system for individual subjects. In this final section, Pfaller's concepts of disappearance and latent aversion will be used to analyze how the interpassivity of sermon handouts interacts with the "theological niceties" of sermons, and to resolve the question of interpassivity theory's utility for evaluating the value of sermon handouts. ${ }^{145}$

This analysis of sermon handouts is concerned with what is left of the epistemic experience for worshippers once they become interpassive subjects. Borgmann believes it is ultimately an ethical question how technology contributes to or detracts from one's experience of being. ${ }^{146}$ Church members who are concerned with fidelity in worship will acknowledge this concern as it relates to the mediation of technology as seen in sermon handouts. Pfaller raises this concern when he describes the heavily mediated experience: “"For they know not what they believe' - this would be, in biblical terms, the formula for the civilized position towards the illusion at work in interpassivity." 147 This is a primary critique for the interpassivity of sermon handouts: disappearance of substance.

The form of worksheet that is most problematic in this way is the "oversaturated" category. In practice, these worksheets are issued upon the beginning of worship services. Research suggests these would be the ideal form of worksheet if they were provided at the conclusion of services, as worshippers prepare to go home. ${ }^{148}$ The richness of the material provided on these worksheets would invite better recall and support the educational development of congregants. Instead, the oversaturated worksheets induce an experience which is subject to a degree of interpassivity which

\footnotetext{
144 Benjamin Blair Phillips, "Fellowship of the Triune God," 22

145 Robert Pfaller "The familiar unknown, the uncanny, the comic, the aesthetic effect of thought experiments" in Lacan: The Silent Partners, ed. Slavoj Žižek (London: Verso) 2005: 27; Robert Pfaller, Interpassivity, 53-66; Marx and Engels, Capital, 47

146 Albert Borgmann "Reality and Technology," 31

147 Pfaller, Interpassivity, 58.

148 Richard B. Larson, "Enhancing the Recall of Presented Material." Computers \& Education, 53: 4 (2009): 12781284.
} 
Pfaller describes as "disappearance." 149 Just as the "oversaturated" worksheets lend themselves to disappearance for their richness of content, the "blank" worksheets are subject to experiences of disappearance for the abundance of freedom they grant worshippers.

While his examples are prolific, some examples of Žižek's interpretations of disappearance are overreaching and overly-broad. Žižek imagines the interpassive subject totally vanishing as her labor is completely delegated to the object. The experience is hers completely only through the interpassive object. Žižek's example of prayer-wheels that do the praying for the interpassive subject, rendering the subject free to engage in filthy thoughts as the interpassive object engages the labor of pious contemplation, is a primary example. ${ }^{150}$ Briefly, the absolute disappearance of the subject (Selbstvergesenheit) is more successful in Lacanian and Freudian theories of psychoanalysis than in practice. Žižek's diagnosis of exactly what kind of experience is being had (phenomenology) defeats the ontological foundation assumed by the interpassivity paradigm itself. If the subject totally disappears, fully delegating the labor of experience to the interpassive object to the point, then wholesale interpassivity becomes interactivity. Full disappearance negates the pleasure of the knowledge of one's own disappearance, which corrupts Pfaller's theory of interpassivity, which assumes the subject is aware of this pleasure to some degree.

Van Oenen's interpretation of "disappearance" is more applicable here. He sees disappearance, specifically in labor, in outsourcing, a determination that the work "may as well, or better, be done elsewhere". ${ }^{151}$ Other activities related to church, within and without these congregations, can be read this way. Individual worshippers may outsource the labor of singing to the choir, or missionary work (foreign or domestic) to hired missionaries. The choice to pay for food to go to the soup kitchen rather than distributing the food at the soup kitchen is a form of outsourcing. Some parents might outsource the majority of the religious education of their children to Sunday school teachers or youth ministers. The examples are plenty, as churches (including the ones under consideration here) continue to develop programs that minister to an ever-growing range of needs. The decision whether to actively participate in these programs or simply fund others' participation is a matter of outsourcing.

\footnotetext{
149 Pfaller, Interpassivity, 53-66.

${ }^{150}$ Slavoj Žižek The Sublime Object of Ideology (London: Versa,1989), 33

${ }^{151}$ Van Oenen, "A Machine That Would Go of Itself," 4
} 
For Van Oenen, disappearance is embedded within outsourcing. He claims that outsourcing contributes to an alienating experience. ${ }^{152}$ As labor is outsourced, specifically to technology, the interpassive subject experiences the labor in a new, less intimate way. In this way, the worker "disappears" to the degree that she is alienated from the experience of labor. Borgmann sees this detachment from "the burdens of engagement" as problematic. ${ }^{153}$ However, this is not total detachment. Unlike Žižek's disappearance, the subject is still engaged in some level of activity related to the delegated labor. Van Oenen uses Richard Sennett's example of a Boston bakery whose workers' daily experiences of work have shifted due to the introduction of technology into their roles. ${ }^{154}$ Rather than kneading dough by hand, the workers now manage the machines that knead the dough for them. The crucial piece of Van Oenen's reading of this example for analyzing the interpassivity sermon worksheets is his conclusion that due to alienation (disappearance), experiences have lost their "malignant properties, that is to say of their substance, the hard resistant kernel of the Real: coffee without caffeine, cream without fat, beer without alcohol, politics without administration, that is, without politics." 155 His point, which tempers the original interpretation of this Žižekian analogy, is that somewhere within the desire to improve or avoid, values subtly begin to shift from the product to the process by which the product is made. ${ }^{156}$

\section{Conclusions}

Thus, interpassivity for these worksheets can be observed in the following way. Oversaturated worksheets invite disappearance through their weakness as educational tools that call for excessive processing. ${ }^{157}$ And this is not simply because subjects will decline to engage. Rather, this is due to the worksheet's role as a signifier of prior engagement of an unknown party. ${ }^{158}$ The worshipper, seeing such an overwhelming representation of the content that is only

\footnotetext{
152 Ibid, 4

153 Borgmann "Reality and Technology," 31

${ }^{154}$ Van Oenon relies on Sennett's study of the Boston bakery to advance his theory of interpassivity. Richard Sennett, The Corrosion of Character (New York: W.W. Norton, 1998), 68; Van Oenen, “A Machine That Would Go of Itself," 5

${ }^{155}$ Van Oenen, “A Machine That Would Go of Itself," 10

156 Slavoj Žižek Welcome to the desert of the real (London: Verso, 2002), 10-11. This is described more thoroughly by Pfaller, who calls this motivation "latent aversion". This concept will appear in the proceeding discussion.

157 Baddeley, "The episodic buffer," 417-423.

158 This is slightly different from the experience of pupils who receive complicated handouts upon entering class. In this case, church members are not attending with the anticipation of managing an academic exercise only (as students
} 
now being presented to them in the actual sermon, may assume that the labor of engaging with the content is "better off" done by the party responsible for producing the worksheet. The result of this outsourcing can then be described as "attendance without presence," which provides a more efficient outcome and allows worshippers to "disappear," avoiding the rigor of labor, freeing them to manage more pleasurable facets of the experience.

However, this alienation influences how church members benefit from the "theological niceties" within worship through the sermon. ${ }^{159}$ All versions of the worksheets considered here, like the oversaturated worksheets, invite some measure of disappearance. This is further problematized when the value of handout materials as educational tools intersects with the disappearance of disciples by delegation. This confluence demonstrates Van Oenen's concern that, as technology consumes the substance of our labor, we shift the focus from the product to the process by which the product is made. The role of the worshipper, unconsciously, shifts from producer to manager. The Boston bakers slowly developed an expertise for maintaining the day to day functions of the automation process and lost their connection to the tactile experience of making the products themselves. Interpassivity can shift the experiences of worship from substantial to procedural. This could be demonstrated in practice in the haste of worshippers who have concluded the worksheet and begin putting away their Bibles and study materials, even as the sermon is still taking place. The value, it seems, has shifted from experiencing the sermon, which yields communion within a Trinitarian conversation, to the process of completing the worksheets designed to serve as a tool to foster this as an interior experience for the worshipper.

This shift of values from product to process takes a toll on the experience of worship. Worksheets, acting as signifiers of ideology, do confirm belief. Yet, these rituals reassure worshippers of the existence of other believers rather than the existence of God. ${ }^{160}$ Sustaining this exercise in interpassivity may reinforce the worshipper's awareness of God and a community of believers, but it does come at a cost. It is possible to believe through the big Other, but it is impossible to know through it. ${ }^{161}$ Here, symbolic efficiency and Phillips' Trinitarian theory of

might). Instead, members attend with the expectation of managing the much broader task of worship. The labor of learning is more likely to be delegated to the oversaturated handout, allowing the subject to disappear into other realms of worship.

${ }^{159}$ Marx and Engels, Capital, 47

${ }^{160}$ Pfaller, Interpassivity, 243.

161 Žižek, "The Interpassive Subject" 
sermons are at odds. To the degree worshippers are participate and benefit from one, they are absent from the other.

Again, Borgmann sees the loss of epistemic substance through delegated labor as an ethical matter that must be addressed. The answer, he insists, is not an "all or nothing affair."162 This shines some hope on the practice of sermon handouts, which do offer real value for worshippers as educational tools and study aids. Worksheets, after all, were not introduced malevolently. The intent of church leaders was hardly to nudge worshippers into disappearance and the abdication of communion; it is doubtful that worshippers would genuinely desire these symptoms of interpassivity either. Worksheets were not developed with the intent of avoiding worship. Rather, the expense churches incur through producing and circulating these worksheets suggests their purpose is to support engagement with spiritual matters rather than the alternative. Interpassivity and its symptoms are a phenomenon, not the plot of lazy church members or misguided leaders.

In fact, this is precisely how Pfaller proposes interpassivity can come about in certain instances. At times, we inadvertently perform the task we wish to avoid (interpassively) through our efforts to obviate our latent aversions. ${ }^{163}$ His example are bibliophiles who give and receive books, only to never read them knowing that they have avoided the undesirable identity of someone who doesn't care for reading books. For these churches, worshippers are subject to disappearance by completing worksheets that have been thoughtfully incorporated into worship to engage their attention and avoid poor reception of the sermon. Pfaller suggests that compulsive actions to avoid some restricted object can inadvertently subvert the strategy of the original practice. ${ }^{164}$ Here, the concept of symbolic efficiency contributes creates a negative experience. By responding to preaching, mindful of the "naïve third party" who would require intense study materials to hold their attention, church leaders have instituted a practice that is utilized as a means of outsourcing engagement rather than focusing it.

The potential for rituals to go amiss does not disqualify rituals. It is possible for church members to enjoy hymns for musical reasons rather than spiritual ones, but the practice of singing polyphonic hymns remains. Cults of personality can and do develop around preachers, yet the pastoral vocation is still thought of as a viable contribution to churches. The phenomenon of

\footnotetext{
162 Borgmann "Reality and Technology, " 35

163 Robert Pfaller, On the Pleasure Principle in Culture: Illusions Without Owners (New York: Verso, 2014), 27

164 Ibid, 27
} 
interpassivity is a part of living in a world replete with technology and the new challenges that emerge with progress. Borgmann names human agency as the force that protects sacred, ontological experiences in labor: it is entirely up to our mindfulness. ${ }^{165}$ By "tempering contexts of engagement", the negative symptoms of interpassivity can be managed and the positive leveraged for more cerebral, sacramental worship. Therefore, interpassivity theory is helpful for church leaders to consider as they organize worship services and design sermon handouts. This theory has shown that even in sacred places and practices, worshippers are subject to forces that can inadvertently challenge and enhance their reception of God's presence.

165 Borgmann "Reality and Technology," 34 


\section{BIBLIOGRAPHY}

Althaus, Paul. The Theology of Martin Luther. Philadelphia: Fortress, 1966.

Augustine. On Christian Doctrine, BookIV.

Avval Farnaz, Jarahi Lida, Ghazvini Kiarash, and Youssefi Masoud. "Distribution of Handouts in an Undergraduate Class to Create More Effective Educational Environment." International Journal of Educational Research 12, no. 1 (2013):107-113.

Baddeley, Alan. "The Episodic Buffer: a New Component of Working Memory? Trends in Cognitive Sciences.” Psychology of Learning and Motivation 4, no. 11 (2000):48-79.

Burton, Z. Cooper and John S. McClure. Claiming Theology in the Pulpit. Louisville, Kentucky: Westminster John Knox Press, 2003.

Carroll, Lori. "Communication Training for Clergy: Exploring Impact on the Transformative Quality of Sermon Communication.” Communication Education 58, no. 1 (2009): 15-34.

Craddock, Fred B. As One without Authority, rev. ed. St. Louis: Chalice Press, 2001.

Dharmasaroja, Permphan. “Do Medical Students Really Need Lecture Handouts?” Medical

Teacher 36, no. 10, (2014): 914-915, https://doi.org/10.3109/0142159X.2014.940875

Frame, John. The Doctrine of the Word of God. Phillipsburg, NJ: P \& R Publishing, 2010.

Freiré, Paulo. Pedagogy of the Oppressed. Harmondsworth: Penguin 1972.

Freud, Sigmund. (1907). Obsessive Actions and Religious Practices. The Standard Edition of the Complete Psychological Works of Sigmund Freud, Volume IX (1906-1908): London: Hograth Press 1959.

Gutierrez, Ricardo. "Reinventing the Notion of Ethics: Žižek on the Invisible Violence of Capitalism.” International Journal of Žižek Studies 8, no. 2 (2014): 1-11.

Hartlely, James and Allen Cameron. "Some Observations on the Efficiency of Lecturing." Educational Review 20 (1967): 30-37.

Hiroshi, Ito. "Rethinking Active Learning in the Context of Japanese Higher Education." Cogent Education 4, no. 1 (2017): 1-11.

Jagodzinski, Jan. “Interpassivity.” Continental Thought and Theory 2: no. 1 (2018): 270-297.

Jarvis, Peter. "Religious Experience: Learning and Meaning." Transformation 25, no. 2-3 (April 2008): 65-72, https://doi.org/10.1177\%2F026537880802500301.

Kendall, R.T. "Preaching in Worship." Themelios (April 1979): 88-92.

Kinchin, Ian. "Developing PowerPoint handouts to support meaningful learning." British Journal of Educational Technology 37, no. 4 (2006): 647-650.

Larson, Richard B. "Enhancing the Recall of Presented Material." Computers \& Education 53, no. 4, (2009): 1278-1284.

Mannoni, Octave. Clefs pour I'maginarire ou l'autre scene. Paris: Seuil 1985.

Marx, Karl and Friedrich Engels. Capital: A Critique of Political Economy. London: Electric Book Company, 2001. Kindle. 
Mercer, J. A. "Transformational Adult Learning in Congregations." The Journal of Adult Theological Education 3: no. 2 (2006): 163-178.

Mezirow, Jack. "A Critical Theory of Adult Learning and Education." Adult Education: 32, no. 1 (September 1981): 3-24. https://doi.org/10.1177/074171368103200101.

Milbank, Alison, John Hughes, and Arabella Milbank. Preaching Radical and Orthodox: Sermons for the Christian Year. London: SCM, 2017.

O’Lynn, Robert. "Developing a Transformative Theology for Preaching." International Journal of Homiletics, Volume 3 (2018):99-112

Otto, Rudolf. The Idea of the Holy: An Inquiry Into the Non-rational Factor in the Idea of the Divine and Its Relation to the Rational. Harmondsworth: London, Penguin (1917)

Pargament, Kenneth I. and Donald V. DeRosa. "What was that sermon about?" Journal for Scientific Study of Religion 24 (1985): 180-193.

Pfaller, Robert. Althusser: Das Schweigen im Text. Munich: Fink, 1997.

"The Familiar Unknown, the Uncanny, the Comic, the Aesthetic Effect of Thought Experiments," In Lacan: The Silent Partners, edited by Slavoj Žižek, 198-216. London: Verso, 2005.

Die Illusionen der anderen: Uber das Lustprinzip in der Kultur. Frankfurt: Suhrkamp, 2002.

-Interpassivity: The Aesthetics of Delegated Enjoyment. Edinburgh: Edinburgh University Press, 2017.

Phillips, Benjamin Blair. "Fellowship of the Triune God: The Divine Context for a Theology of Preaching." The Journal of the Evangelical Homiletics Society 16, no. 2 (September 2016): $15-28$.

Piolat, Annie, Thierry Olive and Ronald T. Kellogg, "Cognitive Effort During Note Taking." Applied Cognitive Psychology, 19 (2005): 291-312, https://doi.org/10.1002/acp.1086.

Quicke, Michael. "Preaching Outcomes.” Evangel 17:2 (Summer 1999): 58-62.

Reid, Clyde. The Empty Pulpit. New York: Harper \& Row, 1967.

Robinson, Haddon. Biblical Preaching. Grand Rapids: Baker, 1980.

Rowe, Arthur. "Preaching and Teaching." Evangel 17:2 (Summer 1999): 48-50.

Runia, Klass. "What is Preaching According to The New Testament?" Tyndale Bulletin 29: (1978): $3-48$.

Rystad, Linn Sæbø. "I Wish We Could Fast Forward It: Negotiating the Practice of Preaching." Homiletic 44, no. 2 (2019): 1-25.

Sato, Tomohiko \& Mitachi, Mami \& Okada, Tetsutaro. "Implementation of Active Learning Strategies in a Large-Enrollment Economics Class at a University." Conference: 7th International Congress on Advanced Applied Informatics (IIAI-AAI) (2018).

Sennett, Richard. The Corrosion of Character. New York: W.W. Norton, 1998.

Steiner, George. Real Presences. Chicago: University of Chicago Press, 1991. 
Stevenson, Geoffrey and Stephen Wright, eds. Preaching with Humanity: A Practical Guide for Today's Church. London: Church House Publishing, 2008.

Stott, John. "A Definition of Biblical Preaching." In The Art and Craft of Biblical Preaching: A Comprehensive Resource for Today's Communicators, edited by Haddon Robinson and Craig Brian Larson, 14-20. Grand Rapids: Zondervan 2005.

Stuart, Johnathan. "Applying Adult Education Principles within Church Sermons: Some Theoretical Implications." Journal of Adult Theological Education 8, no. 2 (2011): 115129.

Thomson, Jeremy. Preaching as Dialogue: Is the Sermon a Sacred Cow? Cambridge: Grove, 1996.

Tufte, Edward R. The Cognitive Style of PowerPoint. Graphics Press (2003).

Van Oenen, Gijs. "A Machine That Would Go of Itself: Interpassivity and Its Impact on Political Life." Theory and Event 9, no. 2 (2006): 1-16.

Vanhoozer, Kevin. Remythologizing Theology: Divine Action, Passion, and Authorship. Cambridge: Cambridge University Press, 2010.

Voelz, Richard. "Reconsidering the Image of Preacher-As-Teacher: Intersections Between Henry Giroux’s Critical Pedagogy and Homiletics.” Analyzing Matters, Issue 7 (March 2014):7691

Warnick, Bryan R. and David Waddington. "The Gathering: An Ethical Criterion for Educational Technology." Educational Technology 44, no. 5 (September-October 2002), https://www.jstor.org/stable/44428933.

Williamson, Clark M. and Ronald J. Allen. The Teaching Minister. Louisville: Westminster/John Knox, 1991.

Wilson, Paul Scott. The Practice of Preaching. Nashville: Abingdon, 1995.

Wood, A. Skevington. Captive to the Word: Martin Luther, Doctor of Sacred Scripture. Exeter: Paternoster, 1969.

Worley, Robert C. Preaching and Teaching in the Earliest Church. Philadelphia: Westminster, 1967).

Žižek, Slavoj. “A Cup of Decaf Reality.” Lacan.com, https://www.lacan.com/zizekdecaf.htm “The Interpassive Subject.” Lacan.com, https://www.lacan.com/zizek-pompidou.htm

-The Plague of Fantasies. London: Verso, 1997.

-The Sublime Object of Ideology. London: Verso 1989.

Welcome to the Desert of the Real. London: Verso, 2002.

“'Will You Laugh for Me Please?” Lacan.com, https://www.lacan.com/zizeklaugh.htm 